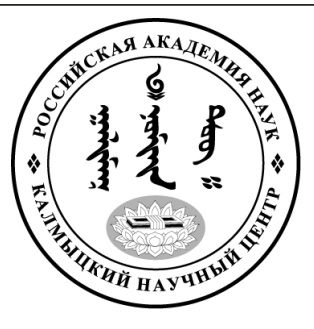

Published in the Russian Federation

Oriental Studies (Previous Name: Bulletin of the Kalmyk Institute

for Humanities of the Russian Academy of Sciences)

Has been issued as a journal since 2008

ISSN: 2619-0990; E-ISSN: 2619-1008

Is. 5, pp. 1026-1033, 2019

DOI: $10.22162 / 2619-0990-2019-45-5-1026-1033$

Journal homepage: https://kigiran.elpub.ru

УДК 398.21(470.47)

\title{
Мотив отправления героя, рожденного от медведя, в сказочной традиции тюрко-монгольских народов
}

\section{Евдокия Эрендженовна Хабунова ${ }^{1}$, Чао Геджин ${ }^{2}$}

${ }^{1}$ Калмыцкий государственный университет им. Б. Б. Городовикова (д. 11, ул. Пушкина, 358000 Элиста, Российская Федерация)

доктор филологических наук, профессор, директор Международного научного центра «Культурное наследие монгольских народов»

ORCID: 0000-0002-2113-6877. E-mail: khabunova@mail.ru

${ }^{2}$ Институт национальных литератур Академии общественных наук КНР (1106, просп. Цзяньгуомэньнэй, 100732 Пекин, Китай)

доктор филологических наук, профессор, директор

ORCID: 0000-0001-9206-8181. E-mail: chao@cass.org.cn

Аннотация. Актуальность проблем типологии становится все значимей в контексте расширяющихся межэтнических коммуникативных связей: фольклорных, культурных, социально-бытовых и т. д. Многие сказочные сюжеты, мотивы, переходя из одной традиции, страны в другую, от народа к народу, обрастая все новыми и новыми вариантами, меняя свой художественный облик, в зависимости от новой среды бытования, сохраняют свою ядерную основу, способствующую формированию сюжетных типов. Вместе с тем эти ключевые элементы в сказочных традициях разных народов ведут себя не совсем типично. Цель исследования.Статья нацелена на сравнительное изучение мотивировки отправки героя, вступившего в борьбу со своим зооморфным родителем, порвавшего с прошлым, но в процессе социализации столкнувшегося с трудностями, заставившими его покинуть общину. Базируясь на анализе двенадцати образцов сказок тюрко-монгольских народов с типовым сюжетом «медвежий сын», мы определили «причины» и «цели» отправки героя из социума и проследили характер вариативности, «непостоянства», «неустойчивости» мотивировки как элемента сказочного сюжета. Memoдbl исследования. Отталкиваясь от структурно-типологического метода В. Я. Проппа, используя в исследовании основные позиции компаративистики, позволяющие выявить аналогии и различия в разных национальных традициях, и привлекая отдельные приемы структурно-семантической методики, разработанной Б. П. Кербелите, авторы пришли к следующим выводам: «непостоянство», «нечеткость», вариативность мотива проявляются в детализации действий героя, отражают национальную специфику и подтверждают закономерность «подвижности» периферийных элементов мотива.

Ключевые слова: сказка, типология, национальные традиции, герой, зооморфные особенности, социум, отправка, мотивировка

Благодарность. Исследование выполнено при финансовой поддержке РФФИ и Академии общественных наук Китая в рамках научного проекта № 19-512-93002.

Для цитирования: Хабунова Е. Э., Чао Геджин. Мотив отправления героя, рожденного от медведя, в сказочной традиции тюрко-монгольских народов. Oriental Studies. 2019;(5): 10251033. DOI: 10.22162/2619-0990-2019-45-5-1026-1033. 
UDC 398.21(470.47)

\title{
Fairy-Tale Tradition of the Turko-Mongols: Motives for the Expulsion of a Bear-Born Hero
}

\author{
Evdokia E. Khabunoval, Chao Gejin ${ }^{2}$
}
${ }^{1}$ Gorodovikov Kalmyk State University (11, Pushkin St., Elista 358000, Russian Federation)
Dr. Sc. (Philology), Professor, Director of International Scientific Centre 'Cultural Heritage of Mongolic Peoples'
ORCID: 0000-0002-2113-6877.E-mail: khabunova@mail.ru
${ }^{2}$ Institute of Ethnic Literature, Chinese Academy of Social Sciences (1106, Jianguomennei St., Beijing 100732, People's Republic of China).
Dr. Sc. (Philology), Professor, Director
ORCID: 0000-0001-9206-8181. E-mail: chao@cass.org.cn

\begin{abstract}
Introduction. The issues of typology are becoming increasingly significant in the context of expanding interethnic communicative ties, such as folklore, cultural, social ones, etc. Many fairytale plots, motifs - moving from one tradition, country to another, from people to people, developing more and more versions, changing their artistic appearances depending on new environments of their existence - retain their nuclear bases, which facilitates the formation of certain plot types. At the same time, these key elements do not function quite typically in fairy-tale traditions of different nations. Goals. The article contains a comparative study of motives for the expulsion of a hero who has broken with the past and taken up arms against his zoomorphic parent, but during the socialization faces certain difficulties that force him to leave the community. The paper analyzes twelve fairytale samples of Turko-Mongolic peoples with the typical plot 'son of the bear', determines the 'reasons' and 'goals' of exiling the hero from society, traces the essential variability, 'inconstancy', and 'instability' of motives as an element of the fairy tale plot. Methods. The work employs the structural-typological method of V. Propp, turns to key comparative research positions that make it possible to identify analogies and differences in various national traditions, uses certain techniques of the structural-semantic methodology developed by B. Kerbelite. Conclusions. The 'inconstancy', 'fuzziness', and variability of motives are manifested in details of the hero's actions, reflecting the national specificity and confirming the law of 'mobility' of peripheral elements of the motif.

Keywords: fairy tale, typology, national traditions, hero, zoomorphic features, society, departure, motivation

Acknowledgements: The reported study was funded by RFBR and CASS according to the research project № 19-512-93002

For citation: Khabunova E. E., Gejin Ch. Fairy-Tale Tradition of the Turko-Mongols: Motives for the Departure of a Bear-Born Hero. Oriental Studies. 2019;(5): 1026-1033. DOI: 10.22162/26190990-2019-45-5-1025-1033.
\end{abstract}

\section{छ}

\section{Введение}

Сказка является одним из занимательных жанров устного народного творчества о противоборстве добра и зла, о вере в торжество справедливости и, как правило, со счастливым финалом. Этот позитивный посыл послужил главным фактором активного продвижения сказочных сюжетов и мотивов в пространстве, мощным рычагом проникновения в социум сказочных идей и образов, отражающих общечеловеческие ценности, что естественным образом повлияло на формирование типологического сходства сказочных сюжетов, нашедших отражение в различных указателях [СУС 1979; Кербелите 2005; Uther 2004].

Под типологией принято понимать «закономерную, обусловленную рядом объективных факторов повторяемость в природе и обществе, которая обнаруживает себя в 
предметах и явлениях, в свойствах и отношениях, в элементах и структурах, в процессах и состояниях» [Путилов 1976: 9]. Характер типологического сходства может быть определен лишь при внимательном изучении всех уровней повторяемости, включая самую минимальную «повествовательную единицу» фольклорного нарратива.

Проблема типологии остается одной из актуальных в мировой фольклористике, и она становится все важней в контексте расширяющихся коммуникативных связей: фольклорных, культурных, этнических, социально-экономических и т. Д. В этом контексте представляется перспективным обращение к вопросу межэтнических фольклорных связей в части выявления общих и специфических явлений в устной традиции, в частности, в сказочном фольклоре разных народов, родственных и неродственных этнически, но тесно взаимодействовавших на протяжении длительного времени.

Фольклористика не отрицает возможность факта передачи отдельных сказочных сюжетов из одной страны в другую, от одного народа к другому. Встречаясь со сходством сюжетов в фольклоре разных народов, она учитывает не только возможность заимствования, но и допускает совпадение сюжетов в результате народного творчества, развивавшегося в сходных общественно-исторических, культурно-бытовых условиях каждого региона [Пропп 2001; Жирмунский 1967; Путилов 1976; Гацак 1967; Кербелите 2005] и др.

В любом случае тот или иной сюжет, попадая в новые условия, проникая в новую фольклорную среду, адаптируясь в этнической культуре, проходит творческую переработку, что впоследствии формирует национальную специфику и художественное своеобразие сказочного сюжета. Различные типы взаимодействия сказочных сюжетов интерференция, сотворчество, получившие реализацию в «синтезе встречных течений», контаминациях - способствовали пополнению мирового сказочного фонда оригинальными сюжетными типами, региональными версиями интернациональных сюжетов.

Как известно, основной состав национального сказочного фонда представляют сюжеты интернациональные, обусловленные способностью сказки «переходить от народа к народу и перевоплощаться в национальные формы, сохраняя международную структурную основу» [Жирмунский 1967:
283]. Интерес к этим переходящим сюжетам обусловил многообразие терминов и понятий: «бродячие», «странствующие», «международные», «интернациональные». По сути, все эти обозначения передают основные свойства, способствующие жизнестойкости международных сюжетов сказки, - их устойчивость, мобильность, взаимопроникновение. «Изучение типологии этих связей, механизма их действия и масштабов их влияния важно во всех отношениях» [Путилов1976: 180].

Варьируясь и меняя свой художественный облик в зависимости от новой среды бытования, многие сказочные сюжеты сохраняют свою ядерную основу, устойчивость которой обеспечивается набором базовых мотивов (чудесное рождение, стремительный рост, наречение именем, трудное задание, отправление в путь и т. д.). Они легко распознаются в сказочном сюжете, их конструктивность способствует формированию сюжетных типов, основной фонд которых нашел отражение в различных указателях [СУС 1979; Кербелите 2005; Uther 2004]. Вместе с тем эти конструктивные модели, сохраняя свою константную основу, в сказочных традициях разных народов ведут себя не совсем типично. Это особенно часто наблюдается в реализации мотивов, отражающих действия героя или направленных на героя.

В этом контексте представляется $а \kappa-$ туальнылм рассмотреть мотив «отправки героя», типичный для сказочного сюжета, ввиду того, что основные события, изображаемые в сказке, происходят с участием главного героя и за пределами его ойкумены. Выявление причин, побудивших героя отправиться в путь, важно для понимания механизма сложения мотива «отправка героя» как в формальном, так и в содержательном плане. Важно проследить характер взаимоотношений героя с социумом до момента удаления его от семьи, дома, родовой общины, страны и то, как это проявляется в сказочной традиции разных народов: генетически родственных и неродственных, но тесно взаимодействующих на протяжении длительного времени (башкир, бурят, казахов, калмыков, монголов, синьцзянских ойратов, тувинцев, узбеков, хакасов, якутов).

Настоящая работа нацелена на анализ мотивировки отправки героя, рожденного от медведя (медведицы), в редком случае, воспитанного зооморфным родителем. 
Материалом для анализа послужили сказки с сюжетным типом «Медвежье ушко» [СУС 1979], «Чудесная сила или знание (умение)» [Uther 2004], опубликованные в двуязычном издании «Сказки народов Евразии» [Сказки 2017].

Выбор сюжетного типа не случаен, так как главный герой сказки, рожденный от медведя (медведицы) и человека, представляет собой архаический образ человека зооморфного происхождения, вступившего в борьбу со своим зооморфным родителем, т. е. порвавшего с прошлым (умершим и воскресшим), но в процессе социализации столкнувшегося с трудностями, заставившими его покинуть общину.

Базируясь на анализе девяти образцов сказок тюрко-монгольских народов с типовым сюжетом «Медвежий сын», мы определили «причины» и «цели» отправки героя из социума и проследили характер вариативности, «непостоянства», «неустойчивости» мотивировки как элемента сказочного сюжета.

В сюжетном построении рассматриваемых сказок «отправка героя» следует за следующими мотивами: «чудесное рождение», «зооморфный облик», «чудесный рост», «недюжинная сила», «борьба с отцом-медведем (медведицей)», «вхождение в социум», «наречение именем», «отправление в путь» (в бурятской, калмыцкой, синьцзян-ойратской, казахской версиях). В башкирской, тувинской, узбекской, хакасской, якутской версиях сказок из перечисленной выше сюжетной цепочки выпал мотив «борьба с отцом-медведем (медведицей)». Выявление данного мотивного ряда важно для понимания истории, предшествующей отправке героя.

В исследуемых сказках герой, рожденный от медведя (медведицы) или воспитанный медведем, стремительно растет, набирается сил, выбирается из медвежьей берлоги, убивает (оставляет) зооморфного родителя, приходит к людям, получает имя. Казалось бы, процесс социализации сказочного героя протекает благополучно, но его непохожесть создает определенные неудобства для социума и для него самого. Исходная ситуация, обусловленная специфическими чертами героя, оказалась типичной для всех национальных версий, но мотивировка отправления медвежьего сына в путь, т. е. ухода от людей, во всех версиях реализуется по-разному.

Под мотивировкой, согласно В. Я. Проппу, понимаются «причина» и «цель», вы- зывающие героя на те или иные поступки. Она характеризуется ученым как самый непостоянный и неустойчивый, менее четкий и определенный элемент [Пропп 2001: 69]. Именно это свойство «мотивировки» вызывает интерес в плане определения сходства её «непостоянства» и «нечеткости» в разных этнических традициях.

\section{Результаты}

Сказочный нарратив, указывающий причину или цель отправки героя - сына медведя (медведицы) в путь, таков:

В бурятской версии герою скучно среди людей: Баабгайн хүбүүндэ нагасындаа байхадань ехэ уйдахабаритай байба ха. Хүл мүнгэ ябажа, дайда дэлхэй Үзэхэ, харахамни, 一гэжэ баабгайн хүбүYн эхэдээ хэлэбэ гэхэ / 'Жить у родителей своей матери сыну медведя стало очень скучно. - Пойду, не выбирая дорогу, хочу посмотреть на мир и земли, - так, говорят, сказал сын медведя своей матери' [Сказки 2017: 13; 19-20] ${ }^{1}$.

В калмыцкой версии герой желает повидать мир: Аав, нанд һартм бәрх нег тайг кежс өгтн, би нарта орчлизг деер юн болжсахинь эргәд йовад, иинжслдд ирндв», — гинә / 'Дедушка, смастерите и дайте мне в руки посох, я пойду и посмотрю, что происходит на белом свете' [Сказки 2017: 27, 42].

В синьцзян-ойратской версии герой отправляется на поиски равных себе: Тиигәд лом төмрән авч авад, изоклддг бөдүн күчтә дәәсн баәхлд, изоклдна гижс авч, эжсго һазр хәләһдд / 'Взяв свое большое железо, отправился в сторону безлюдного места в поисках достойного противника, с которым можно сразиться' [Сказки 2017: 50, 56].

В башкирской версии герой вынужден уйти из общины из-за конфликтной ситуации с ровесниками, недовольства и жалоб односельчан: Ауылдың бер осонан hyzып ебаргән икән, туп иунда уйна пйөрөгән малайзарзың баштарын өзөп, өйзәрззе емереп, ауылдын икенсе осона сызып киткән. Был хәлдән һун ауыл халкы йыйылган да Айыууволактың атаһына килеп әйткән һинең ульң беззен балаларыбыззй ла, Үзебеззе лә һәләк итер. Һин уны cыzарып ебар. Юкһа, без уны үлтерәбез, - тигәндәр, ти / 'Ударил он по мячику с одного конца аула, а мяч полетел, снося головы играющим ребятишкам, разрушая дома, на другой конец аула. После этого случая односельчане со-

1 В ссылке указывается источник на оригинальный текст, через точку с запятой дается ссылка на перевод сказки на русский язык. 
брались, пришли к отцу Аюголака и сказали ему: Твой сын погубит всех наших детей и нас. Ты его выпроводи из аула. Иначе мы его убьем' [Сказки 2017: 61, 71-72].

В казахской версии для отправки героя из общины послужил ряд причин: недовольство соплеменников, конфликтная ситуация с ровесниками, угроза его жизни, поиски равных себе: Елге сыймай басқ̧а жігіттердің мазасын ала берген соң барльқ жігіттер больи басын құосыл Аюбаланы өлтірмекші болады. Аюбала оны сезіп, шешесімен қ̧оштасыл, беті ауван жақққа қ̧ашыл кетед $i$ / 'Так он быстро нажил себе врагов, все молодые парни собрались и решили расправиться с Аюбала. Аюбала почувствовал что-то неладное, попрощался с матерью и убежал, куда глаза глядели' [Сказки 2017: 75, 82].

В тувинской версии поводом для отправки героя послужили его обжорство, конфликтная ситуация с ровесниками, недовольство соплеменников: Аалга келгеш, бүдүн инекти бүдүнү-биле, бүдүн хойну бүдүнүбиле чиптер ьпшкажыңыл. «Мал-маганның когун үзе чий берди, амытанның ажь-төлүн дөгерезин өлүрер дей берди ьишкажыл» дээш, сээн ужун кончудуп турар кижи-дир мен, оглум - деп / 'Когда приходишь домой, целую корову целиком, целого барана целиком один съедаешь ведь. «Ещё чуть-чуть, от скота ничего не оставит, народа детей всех убъёт», так ругаются, из-за тебя ругают меня, мой сын, сказал [старик]' [Сказки 2017: 99, 118].

В узбекской версии герой оказался в конфликтной ситуации со сверстниками, с властью, на него стали жаловаться соплеменники, ему дают трудновыполнимые и опасные для жизни задания: Бола ундан хуолахвол суррайди. Шунда онаси касали құаттиқлигини, девлар мамлакатида угсадиган хуаё дарахтининг илдизи ва япровини құайнатиб ичмаса одам бўлмаслигини айтсин, дебди. Шундан кейин бола у хуаёт дарахтининг илдизини излашга кетади, қุайтиб келмай$\partial u<\ldots>$ / 'Айик палван отправится искать корень дерева жизни и больше не вернется. И тогда отцы-матери ребят перестанут лить слезы и вопить о спасении, а царь не услышит больше жалоб<...>' [Сказки 2017: 125-126, 135].

В хакасской версии герой вынужден оставить родных в связи с возникшей конфликтной ситуацией со сверстниками и жалобами односельчан и ввиду того, что жизнь становится невозможной: Пазох пір паланың азавын сылы сабысххан. Хараавызылн хоныл альлn, соонуа кён пар сыххан. Мында чуртап полбадыз: азавы хайдаа парча, пазы андар парча, пазы хайдар парча, азағы андар парча / 'Опять одному ребенку ногу сломал. Ночь переночевав, на следующий день из дома отправился. Здесь жить невозможно: его нога куда идет, его голова туда идет, его голова куда идет, его нога туда идет' [Сказки 2017: 138, 144].

В якутской версии у героя возникает конфликтная ситуация с ровесниками (наследниками), затем невеста сжигает его медвежью шкуру: Эһэуола Миишкэ Мэхээлэни нэсилиэнньиктэр абаaһbl көрөллөр... Сассыарда эһэ туран тириитин көрдүҮр да булбат уонна этэр: «Дьэ, эн мин тириибин эрдэ һуох гыммыккиын, онон мин барабын», - диир да, туран таххан баран хаалар / 'Медвежьего сына Мишку-Михайло наследники невзлюбили <..> Так живя, однажды девушка, стащив медвежью шкуру, бросает ее в смолу. Утром медведь встает, ищет свою шкуру, но не находит и говорит: «Ну, ты мою шкуру рано уничтожила, поэтому я ухожу», - сказав так, уходит' [Сказки 2017: 148, 151].

Если обобщить виды мотивировок (они выделены в текстах жирным шрифтом), побудившие героя-сына медведя (медведицы) отправиться в путь, т. е. уйти из общины, можно выделить следующие тематические группы: калм.);

- желание посмотреть мир (бурят.,

- поиск равных себе (синцз.-ойрат., казах.);

- конфликтная ситуация со сверстниками (башкир., казах., тувин., узбек., хакас.);

- конфликтная ситуация с властью (узбек.);

- недовольство и жалобы соплеменников (башкир., казах., тувин., узбек., хакас.);

- обжорство (тувин.);

- прямая угроза жизни (казах., узбек.);

- сожжение медвежьей шкуры невестой, молодой женой (якут.).

Как видно из перечня, мотивировка отправки героя носит двойственный характер: герой отправляется в путь по собственной воле и с определенной целью (в сказках бурят, калмыков, синьцзянских ойратов), и герой отправляется в путь при вынужденных обстоятельствах с целью, иногда бесцельно, т. е. «куда глаза глядят» (в сказках башкир, казахов, тувинцев, узбеков, хакасов, якутов). 
Примечательно, что в первой группе оказались сказки генетически родственных монгольских народов, некогда обитавших в едином номадном пространстве (бурят, калмыков и синьцзянских ойратов), а во второй группе - сказки башкир, казахов, тувинцев, узбеков, хакасов, якутов - генетически родственных и неродственных, тесно взаимодействовавших или территориально отдаленных друг от друга народов.

Обратимся к анализу сказок, попавших в первую группу, и, основываясь на показаниях текста, попытаемся подробно рассмотреть ситуации, предшествующие отправлению сказочного героя в путь по доброй воле.

В бурятской сказке «Сын медведя» $(Б a-$

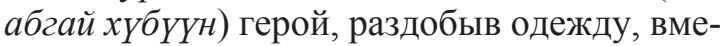
сте с матерью прибывает к её родителям. Их встречают с радостью, затем все вместе живут счастливо. Но со временем сыну медведя становится скучно, и он отправляется в путь, чтобы посмотреть на мир и земли. Никто его не удерживает, провожают с напутствиями и добрыми пожеланиями: Баабгайн хүбүҮндэ нагасындаа байхадань ехэ уйдахабаритай байба ха. 'Жить у родителей своей матери сыну медведя стало очень скучно’ Олзотой, омогтойя баарайш, - гэбээхэнь. 'Отправляйся с пользой и отвагой, - напутствовала его мать’ [Сказки 2017: 13].

В калмыцкой сказке «Сын медведя Алвт Хар» (Аюһин ковүн Алвт Хар) медвежий сын также выглядит вполне социализированным: наречен именем, носит одежду, играет с детьми, любим родными. Он удивляет родных своим стремительным ростом и невиданной силой (сөөднь сөмөсәд, өдртнь алд өсәд бәәнә) [Сказки 2017: 27]. По просьбе внука дед заказывает кузнецу посох, который доставляется внуку на телеге. Испытывая прочность посоха, медвежий сын одной рукой сгибает его в дугу. Попрощавшись со своими стариками и родной матерью, мальчик отправляется в дальнюю дорогу, чтобы повидать мир: «Аав, нанд һартм бәрх нег тайг кежс өгтн, би нарта орчлизг деер юн болжсахинь эргәд йовад, иинжсләд ирнәв», - гинә [Сказки 2017: 27, 42]

Вполне миролюбиво расстается с родными герой сказки синьцзянских ойратов «Богатырь медведь» (Аюбаатр). По случаю возвращения дочери с сыном хан устраивает пиршество. Обнаружив его могучую силу, он приказывает сделать ему из прочного железа оружие огромных размеров, которое никто другой, кроме этого мальчика, не мог сдвинуть с места. За это соплеменники назвали его Аюбаатр. Заполучив небывалое оружие, герой отправляется в путь в поисках достойного противника: Тиигәд лом төмрәнав чавад, ичоклддг бөдүн күчтә дәәсн бдәхлә, ичоклдна гижс авч, эжсго һазр хәләһәд' [Сказки 2017: 50; 56].

Мотивировка отправки героя в бурятской, калмыцкой и синьцзян-ойратской сказках не может быть квалифицирована как изгнание медвежьего сына из социума или избавление от него. Можно наблюдать, что герой принят в семью, ему рады, ничто не предвещает опасности. Сходство исходной ситуации мотивирует похожесть дальнейших действий: герой отправляется в путь по доброй воле, чтобы познать мир, найти достойных противников.

Второй тип мотивировки отправки героя основывается на том, что герой отправляется в путь при вынужденных обстоятельствах. В башкирской, казахской, тувинской, узбекской, хакасской и якутской сказках герой покидает родной дом с определенной целью, иногда бесцельно, т. е. идет куда глаза глядят.

Рассмотрим каждый тип мотивировки по отдельности, так как «предшествующие звенья повествования подготавливают центральный момент, служат ему объяснением и мотивировкой» [Гацак 1967: 178].

Конфликтная ситуация со сверстниками возникает по разным причинам:

- медвежий сын, играя мячом из дубовой чаги, ударяет так, что мяч, пролетая через весь аул, сносит головы детям и разрушает дома (башкирская сказка «Аюголак» (Айыуголак);

- на состязаниях в ловкости и силе соперники медвежьего сына теряют сознание и получают увечья (казахская сказка «Сын медведя» (Аюбала);

- играя с детьми, становится причиной их смерти (казахская сказка «Аюалпан, Судысалпан, Таудыталпан» (Аюалnан, Cyдысалпан, Таудыталпан);

- играя с детьми соседей, ломает им кости (тувинская сказка «Медвежье Ухо» (Адыг-Кулак);

- сбивает с ног и ранит своих сверстников, играя с ними в бабки альчиками из чугуна, каждый весом в десять пудов (узбекская сказка «Богатырь Медведь» (Айиқполвон);

- играя со сверстниками в карты, лишает сознания одного из них, щелкнув его по лбу пальцем (хакасская сказка «Медвежье Ухо» (Аба Хулах). 
Как видно из приведенных данных, конфликт в большей степени возникает в процессе игры, реже - в ходе состязания. Причиной конфликта становится «медвежья сила» героя, которая проявляется по-разному в процессе игры или состязания: она направлена на сверстника-участника игры или на предмет для игры (дубовый мяч, чугунный альчик). В результате «игры» обычный ребенок получает увечья, теряет сознание, умирает, что соплеменниками воспринимается как потенциальная опасность, исходящая от специфического (уродливого, волосатого, неуклюжего, с медвежьими ушками) ребенка. Конфликт с властью также служит мотивацией ухода из общины героя с зооморфными признаками (узбек.).

Мотивировка отправки специфического героя строится не сколько на его сложных отношениях с простыми соплеменниками, связанными с проявлениями могучей медвежьей силы и других зооморфных черт, а на противоречиях, основанных на проблемах социального-классового характера. Юноша выступает в качестве защитника социально обездоленных слоев общества, что неизбежно приводит к конфликту с богатыми представителями власти, затем к изгнанию героя из социума каким-нибудь правителем.

В. Я. Пропп отмечал, что «изгнание может мотивироваться скверным характером героя» и ему придается характер правомерности [Пропп 2001: 69]. Если герой бедокурит, на него жалуются, он глупит, то должен быть наказан. В рассмотренных нами случаях непокорность протагониста и неспособность индивидуума к конформизму расцениваются как отрицательная черта общины, которая не признает его своим и родным, ввиду его особенного происхождения.

Индивидуальные особенности сына медведя и человека дают повод для недовольства и жалоб соплеменников, что также служит мотивацией его ухода от общины. Этот вид мотивировки отправки героя нашел отражение в сказках многих народов (башкир, казахов, тувинцев, узбеков, хакасов). Модель «недовольство и жалобы соплеменников», послужившая поводом для отправки героя в путь, обнаружена нами только в сказках тюркских народов (башкир, казахов, тувинцев, узбеков, хакасов), которые представлены в сборнике «Сказки народов Евразии» [Сказки 2017].

Мотивировка «сожжение медвежьей шкуры», отмеченная лишь в якутской сказке «Медвежий сын Мишка-Михайло» (Эһэу- ола Миискэ Мэхээлэ), существенно отличается от других поводов отправки героя: зооморфный герой уходит не из родовой общины, а от жены (невесты), и причиной тому является потеря медвежьей шкуры. Лишение героя его звериных признаков может приравниваться к утрате им медвежьей силы и «звериного духа», а значит, и магической защиты прародителя. «Сакральное отношение к наиболее значимым частям тела медведя, связанное с идеей их воскресения, составляет наиболее древний пласт в обряде умирающего и воскресающего зверя» [Цыренова 2006]. Сказочный герой, лишившись своего сакрального зооморфного признака (медвежьей шкуры), а значит, магической неуязвимости, вынужден отправиться туда, где нет угрозы для его жизни.

\section{Выводы}

Исследованный материал дает общую картину обстановки, в которую попадает герой до отправления в путь, и того, что побуждает его к решительным действиям. Сам по себе факт пространственного перемещения героя важен как композиционный элемент для дальнейшего развития сказочного сюжета: герой должен пройти через обряд инициации - попасть в другой мир (умереть), проявить себя на чужой стороне и воскреснуть в исходном царстве (государстве), быть признанным (воцарение). Не преодолев испытания, герой не может стать полноправным членом родовой общины и вступить в брак, создать семью с одним из её членов. Эти обстоятельства обеспечили единообразие ядерной основы мотива «отправка героя». Оно выражается в постоянстве элементов: уход героя из общины в младенческом возрасте (играет с детьми); отправление героя в иной мир, участие взрослых (представителей старшего поколения) в отправлении или изгнании героя.

Это единообразие нарушается при детализации мотивировки. Анализ показал, что «беда», «недостача», «трудное задание» не всегда становятся причиной отправки героя в путь.

В одном случае (в сказочной традиции монгольских народов) герой отправляется в путь по доброй воле и поводом для этого служит стремление познать мир и найти равных себе или достойных противников, последнее присутствует в тексте имплицитно, явствует из того, что герой отправляется в путь с оружием из железа (у синьцзянских ойратов) и кованым посохом (у калмыков), без оружия - в бурятской сказке. Незначи- 
тельные разночтения, наблюдаемые в модели мотива, не влияют на её содержательное наполнение, вместе с тем отражают локальные, субэтнические особенности её реализации [Хабунова 2017: 14].

В процессе своего развития сказки стали наполняться новым содержанием, взаимодействовать с другими жанрами, культурными традициями других народов, что способствовало расширению её сюжетного состава и тематическому многообразию мотивно-формульного фонда, появлению локальных, национальных, субэтнических особенностей.

В сказочном фольклоре других народов (башкир, казахов, тувинцев, узбеков, ха-

\section{Литература}

Гацак 1967 - Гацак В. М. Восточно-романский героический эпос. Исследование и тексты: монография. М.: Наука, 1967. 472 с.

Жирмунский 1967 - Жирмунский В. М. К вопросу о международных сказочных сюжетах // Историко-филологические исследования. Сб. ст. к 75-летию акад. Н. И. Конрада. М.: Наука, 1967. С. 283-289.

Кербелите 2005 - Кербелите Б. П Типы народных сказок. Структурно-семантическая классификация литовских народных сказок: в 2-х ч. М.: РГГУ, 2005. 724 c.

Пропп 2001 - Пропп В. Я. Морфология волшебной сказки. М.: Лабиринт, 2001. 192 с.

Путилов 1976 - Путилов Б. Н. Методология сравнительно-исторического изучения фольклора: монография. Л.: Наука, ЛО, 1976. $244 \mathrm{c}$.

Сказки 2017 - Сказки народов Евразии. Сын медведя / сост., автор предисловия Е. Э. Хабунова. Элиста: Изд-во Калм. ун-та, 2017. 199 c.

СУС 1979 - Сравнительный указатель сюжетов. Восточно-славянская сказка/ сост. Л. Г. Бараг, И. П. Березовский, К. П. Кабашников, Н. В. Новиков. Л.: Наука, ЛО, 1979. 437 с.

Хабунова 2017 - Хабунова Е. Э. Этнопоэтические константы сказок монгольских народов: к вопросу о систематизации // Культурные константы монгольских народов: материалы. Элиста: Изд-во Калм. ун-та, 2017. C. $14-19$.

Цыренова 2006 - Цыренова И. С. Медведь в традиционной культуре бурят (историко-генетические и культурно-семантические аспекты): автореф.дис. ... канд.истор.наук. Улан- Удэ, 2006. 20 с.

Uther 2004 - Uther H.-J. The Types of International Folktales: A Classification and Bibliography Based on the System of Antti Aarne and Stith Thompson. Parts I-III. Helsinki: Suomalainen Tiedeakatemia, Academia Scientiarum Fennica. касов, якутов) отправка может рассматриваться как изгнание. На это указывает мотивировка отправки, основанная на том, что «медвежья сила» и другие зооморфные особенности героя создают различные неудобства для социума, а стремление устранить причину неудобств порождает угрозу для жизни героя. Изгнание, которое мотивируется враждой и неприятием героя социумом, формирует вариативность периферийной части устойчивой модели «отправка героя».

Элементы, указывающие на разночтения мотивировок «отправки героя», могут быть квалифицированы как показатели степени подвижности структуры мотива, как свидетельство инвариантности модели мотива.

2004. Part I - 619 p., Part II - 536 p., Part III $285 \mathrm{p}$.

\section{References}

[A Comparative Directory of Plots: the East Slavic Tale]. K. Barag et al. (comps.). Leningrad: Nauka, 1979. 437 p. (In Russ.)

[Tales of Eurasian Peoples: Son of the Bear]. E. Khabunova (comp., foreword). Elista: Kalmyk State University, 2017. 199 p. (In Russ.)

Gatsak V. M. [The Eastern Romance Heroic Epic: Research and Texts]. Moscow: Nauka, 1967. 472 p. (In Russ.)

Kerbelite B. P. [Types of Folk Tales. Structural and Semantic Classification of Lithuanian Folk Tales]. In 2 vols. Moscow: Russian State University for the Humanities, 2005. 724 p. (In Russ.)

Khabunova E. E. Ethno-poetic constants in tales of Mongolic peoples: the issue of systematization revisited. In: [Cultural Constants of Mongolic Peoples: Materials]. Elista: Kalmyk State University, 2017. Pp. 14-19. (In Russ.)

Propp V. Ya. [Morphology of the Magic Tale]. Moscow: Labirint, 2001. 192 p. (In Russ.)

Putilov B. N. [Comparative Historical Research of Folklore: Methodology]. Leningrad: Nauka, 1976. 244 p. (In Russ.)

Tsyrenova I. S. [The Bear in Buryat Traditional Buryat Culture: Historical-Genetic and Cultural-Semantic Aspects]. A Cand. Sc. (history) thesis abstract. Ulan-Ude, 2006. 20 p. (In Russ.)

Uther H.-J. The Types of International Folktales: a Classification and Bibliography. Parts I-III. Helsinki: Finnish Academy of Science and Letters, 2004. (In Eng.)

Zhirmunsky V. M. International tale plots revisited. In: [Historical and Philological Studies: Collected Articles. Celebrating the $75^{\text {th }}$ Anniversary of Acad. N. Konrad]. Moscow: Nauka, 1967. Pp. 283-289. (In Russ.) 